\title{
A 5D Building Information Model (BIM) for Potential Cost-Benefit Housing: A Case of Kingdom of Saudi Arabia (KSA)
}

\author{
Ibrahim Alrashed ${ }^{1}$ and Komali Kantamaneni ${ }^{2, *}$ \\ 1 MOMRA (The Saudi Arabia Ministry of Municipalities and Rural Affairs), Riyadh 13531-3337, Saudi Arabia; \\ eibrahimar@googlemail.com \\ 2 Research and Innovation-Maritime, Technology and Environment Hub, Solent University, Southampton \\ SO14 0YN, UK \\ * Correspondence: Komali.kantamaneni@solent.ac.uk
}

Received: 19 March 2018; Accepted: 4 June 2018; Published: 10 June 2018

\begin{abstract}
The Saudi construction industry is going through a process of acclimatizing to a shifting fiscal environment. Due to recent fluctuations in oil prices, the Saudi construction sector decided to adjust to current trade-market demands and rigorous constitutional regulations because of competitive pressures. This quantitative study assesses and compares existing flat design vs. mid-terrace housing through cost estimation and design criteria that takes family privacy into consideration and meets the needs of Saudi Arabian families (on average consisting of seven members). Five pilot surveys were undertaken to evaluate the property preference type of Saudi families. However, Existing models did not satisfy the medium range family needs and accordingly a 5D (3D + Time + Cost) Building Information Modelling (BIM) is proposed for cost benefiting houses. Research results revealed that mid-terrace housing was the best option, as it reduced land usage and construction costs. While, 5D BIM led to estimate accurate Bill of Quantities (BOQ) and the appraisal of construction costs.
\end{abstract}

Keywords: flats and mid-terrace houses; cost estimation; 5D building information modelling (BIM); Saudi Arabia

\section{Introduction}

Appraisal of costs in construction projects is a significant element for decision making in both the early phase and the later phases. The construction phase based on Quantity take-off (QTO) is purposed for procurement and forecasting construction costs [1]. The significance of sufficient housing for the residents of any nation or society cannot be overstated. Adequate housing is an essential need in every civilization and the value of adequate housing for communities, individuals, families, and society is rarely questioned. Economic prosperity and urban development have been excelling for two decades in the Kingdom of Saudi Arabia (KSA). Economic factors challenge the application of sustainable housing in Saudi Arabia, where an astounding 70 per cent of the population is renting. Even worse, rental accommodations are not sustainable [2]. A study conducted by a Saudi construction company, which gathered information from over 30 real estate developers in the city of Riyadh, found that an average detached house for a single family in the city of Riyadh would cost around \$428,793 [3]. The study also shows that the percentage of Saudi families that can afford to buy this house is around $56 \%$ of the total population of the city of Riyadh. With almost half of the population in the capital city unable to afford to buy or build a house in that budget range, the issue of providing adequate affordable and sustainable housing is vital. 
However, a housing shortage has resulted due to the increases in rental prices $[2,4,5]$. The tremendous increase in demand for new and advanced housing units prompted the use of modern architectural construction methods and design styles. Further, the prominent modern styles include the Western-styled villa and multiple story apartments [6]. Nevertheless, the problem of housing shortage has persisted, especially among low- and middle-income earners. Even when one managed to secure housing, it was neither sustainable, nor efficient in the provision of the cultural needs of the occupants [2]. Accordingly, the kingdom needs to construct 40,000 houses and 500,000 properties for low-pay residents to help facilitate the expanding deficiency and meet the normal populace increase $[7,8]$.

\subsection{Building Information Modelling (BIM)}

Building information modelling (BIM) comprises software to produce a proposal model for a building that responds to change in the way that the actual construction outlines $[9,10]$. It is devised to create a combined and cooperative method to make construction feasible. Many users believe that BIM can be fiscally sophisticated and will ultimately include integrated cost modelling, construction sequencing, and service management competencies [9,11,12]. Moreover, there are two types of BIM software: authoring software and synchronization software [13]. Due to technological evaluation, solitary software packages must be used that encompass both elements. ArchiCAD is a common authoring software program that has been used to create $2 \mathrm{D}$ and $3 \mathrm{D}$ drawings of the proposed Mid-Terrace house. BIM coordination software is hypothetically ground-breaking for building management and contractors. As well, Vico software is useful to take the model that was made by ArchiCAD software and attribute cost, scheduling, and other material to it to make it an instrument for accomplishing amended project distribution [14].

The geometrical information carried by each modeled building component helps coordinate the space conflicts in the building design process, which is also the main benefit of the BIM. For example, the new General Motors (GM) Lansing Delta Township (LDT) Assembly Plant was built 5-8\% under budget and 25\% ahead of schedule by the aid of a well-developed BIM [15]. Eastman et al. [16] shaped the basic building framework while contractors were uploading and updating information about the components they were designing, fabricating, and installing into the BIM. Most of the space conflicts had already been identified within the model before the engineer working on the 2D drawings found some issues. Over 12 months, more than 10,000 interferences were identified and resolved in this project.

\section{2. $5 D$ BIM}

The development of 5D BIM (3D + Time + Cost) is gaining popularity and project cost management organizations are focusing more on this because of its huge advantages. Academic research regarding the implementation of 5D BIM and the vital role the project plays in cost management is attaining vigorous acceptance across the globe [17-20]. Initially, the American Society of Professional Estimators (ASPE), The Association for the Advancement of Cost Engineering International (AACE), and the United States Army Corps of Engineers agreed to work together to resolve cost construction engineering related problems. The primary determination was to improve structures and procedures for the association and management of cost construction engineering and assessing over the development of a project. The association endures to regulate and organize with ever-changing criteria, so that the procedure of separating and processing the 5D (cost) information from the BIM is evidently defined. An Australian quantity-surveying firm (Mitchell Brandtman) market their firm as '5D Quantity Surveyors and BIM Advocates and Specialists'. Mitchell [15] observes this as the 5D 'Living Cost Plan. The evolving research is vital to the emerging nature of 5D BIM application in the construction industry. Evidence relating to 5D BIM usage savings comes from individual participants; i.e., consultants or contractors [21]. The Mansion on Peachtree Atlanta, a \$111 million project, gave a cost benefit of $\$ 15,000$ (Net BIM savings $\$ 6850$ ). 
Many researchers, such as, Forgues et al. [22], Marzouk et al. [23], Azhar et al. [9] Jung and Joo [24], Popov et al. [25], Mills et al. [26]; Broekmaat [27], Wang et al. [28], Russell et al. [29], Mitchell [15], Zhang et al. [30], McCuen [31], Gjøystdal et al. [32] Pishdad-Bozorgi et al. [33], Mouflard [34], Philipp [35], Yung and Wang [36] and Zhou et al. [37] have developed several designs for cost benefit housing in recent periods. They also offer the advantages and disadvantage of 5D BIM, which are the interlinking of costs and time at various capacities. All these designs were deemed unsuitable to the KSA construction environment, both physically and fiscally, however, and did not satisfy most medium range family needs. Accordingly, a 5D BIM proposal for cost benefiting houses that evaluated the fiscal costs of a project for the KSA via the quantitative approach was conducted. In addition, surveys (5 pilot studies) were also conducted to assess the public's choices on the new housing styles across the country. This whole process was assessed by incorporating a methodology; i.e., the Two Path Analysis (2 PA).

\section{Comparison of Housing Styles}

\subsection{Terraced House (UK vs. KSA)}

Individual houses in the form of adjoined rows with a shared common wall have been very popular since the 18th century. These houses look almost identical, with the same height and width. Particularly, these houses are very popular in the United Kingdom from a fiscal perspective. Accordingly, this study applies the style of UK mid-terrace house (Figure 1a,b) (which has found great success in the all parts of United Kingdom) to the KSA to reduce project costs and time by using 2 PA through the assessment of the BIM software programs.

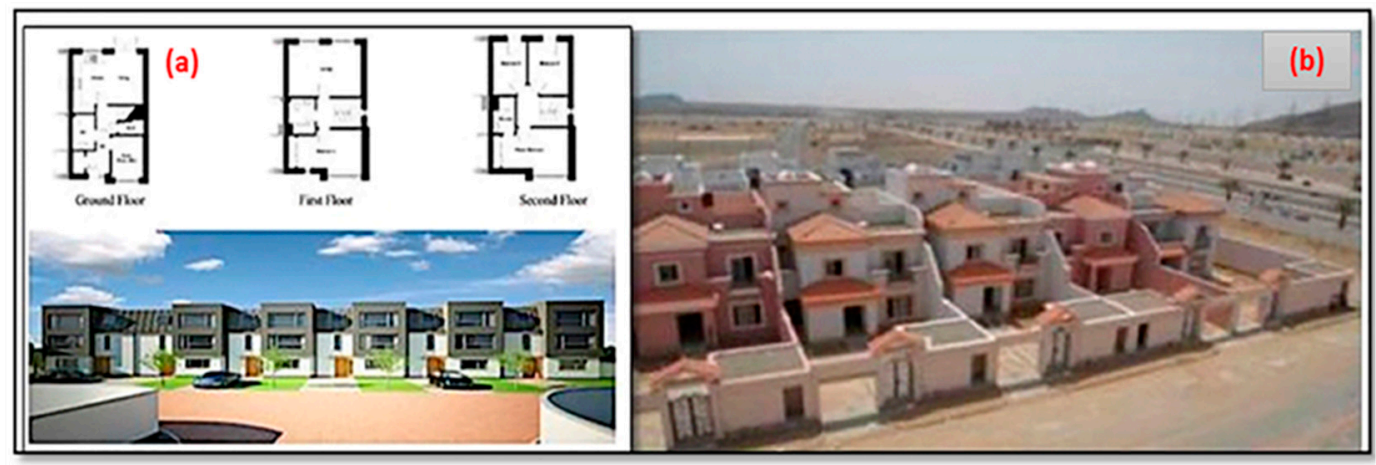

(a)

(b)

Figure 1. (a) Existing Standard Economic Housing Models in the UK, Source: Spring Field [38]; (b) New housing projects in the Kingdom of Saudi Arabia (KSA), 2013, Source: CPI Media Group [39].

\subsection{Flats (UK vs. KSA)}

The continuous uptick in the cost of housing encourages people to live in flats. According to Wang and Li (2006), buying a house/flat is a multi-criteria effort that concerns the type of housing, neighborhood, site, etc. The huge growth of investment in flats is altering the structure of the landscape of property investment [40]. Flats save space enormously, however, most people across the globe, including the KSA and the UK, do not show a huge interest in living in flats. Most councils in the UK built these types of houses (Figure 2a) to satisfy the low and middle-class needs of the people. Similarly, the people of KSA, who have low-income, live in such houses (Figure 2b), but some high-income communities are given the choice to live in very posh flats. 


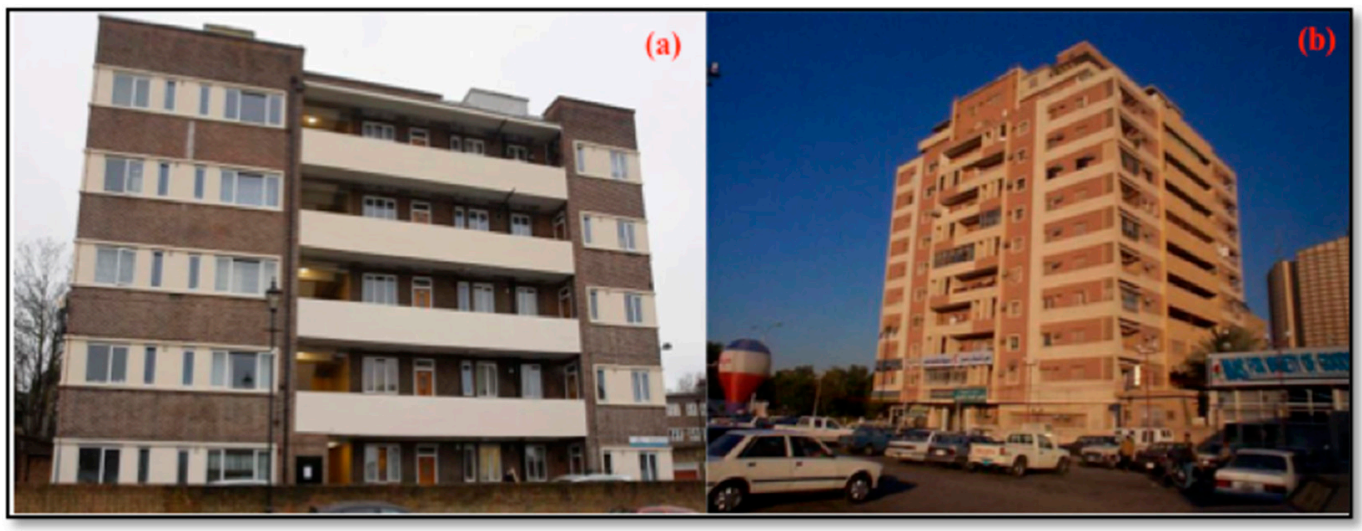

Figure 2. (a) Existing Standard Economic Flat Models in the UK, Source: The Sun [41]; (b) Existing Standard Economic Flat Models in the KSA, Source: GCS International Consulting [42].

\section{Data}

The data (Table 1) were collected from the KSA procurement, housing, and finance departments. While, five surveys were conducted across the KSA in-between January and December 2014 and September 2015, for perceptive consumer choices on dwellings in recent periods. Communicated nearly 510 participants while, only 365 agreed and offered their opinions. Questions were structured in a manner whereby participants were able to understand their intentions and meaning. Due to the cultural restrictions, most of the female candidates did not show an interest in participating. However, telephone surveys were conducted for them with the assistance of female aides to overcome the language and cultural barriers. Survey data, which was analyzed by advanced Excel, was used to understand the people's choices on the housing styles of KSA in recent periods. On the other hand, the collected data regarding construction was analyzed by using the 17th version of ArchiCAD, Vico software to design 5D BIM for cost affecting homes.

Table 1. Data collection and sources.

\begin{tabular}{ccc}
\hline Data Collection & Source & Software for Analysis \\
\hline Method One & KSA procurement, housing, and finance departments & $\begin{array}{c}\text { ArchiCAD } \\
\text { Vico }\end{array}$ \\
\hline Method Two & $\begin{array}{c}5 \text { Pilot Surveys } \\
\text { (At various places of KSA) }\end{array}$ & Advanced Excel \\
\hline
\end{tabular}

\section{Methodology}

Kantamaneni's [43] basic methodological concept has been adopted for the current study to assess and propose the costs and new designs for Flats vs. Mid-Terrace housing via 2 PA (Figure 3). This methodology contains two important phases: Path One (P1) and Path Two (P2). However, this study uses the quantitative approach to develop and evaluate 5D BIM for cost benefiting houses as well as to know the public's opinion of housing styles in KSA. This whole process was done and assessed by incorporating a methodology; i.e., 2 PA. 


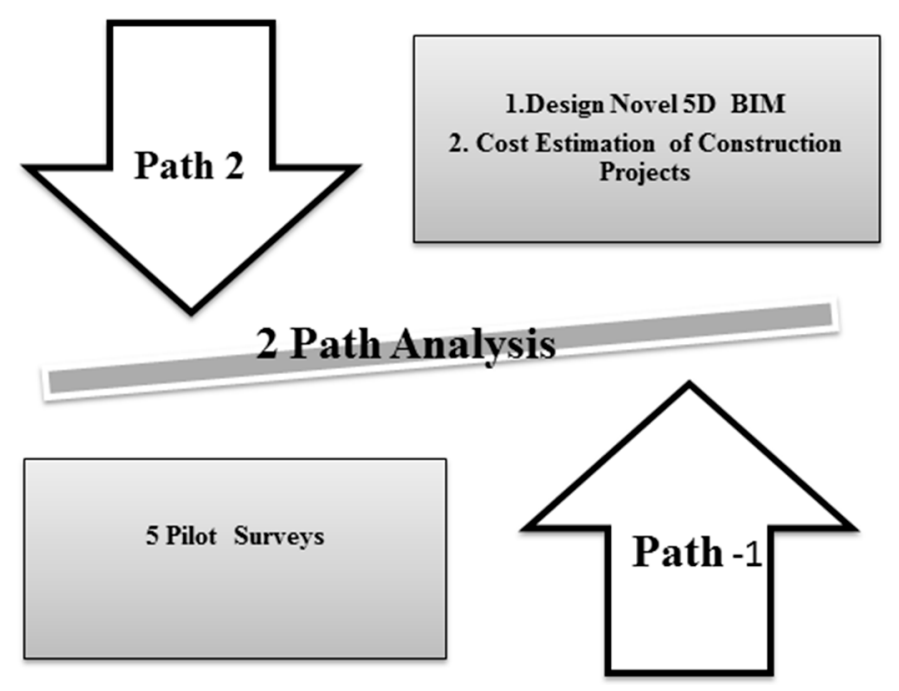

Figure 3. Two Path Analysis (2 PA). Adopted form Kantamaneni et al. [43].

\section{Path One (P1)}

\section{Pilot Surveys}

5 Pilot surveys were undertaken in various parts of the KSA. These pilot studies were undertaken in a 2 vs 3 method; i.e., a survey restricted to only 2 questions (Table 2) with 3 possible answer choices. The questionnaire was distributed to male participants in Jeddah, Riyadh Jeddah, Makkah, Eastern Region, and other places, while female candidates were asked the questionnaire over the phone. Three hundred and sixty five respondents formed the pilot study groups to assess both the methodology and results. These questionnaires were analyzed to appraise the people's options regarding housing styles.

Table 2. Quantitative survey (5 pilot studies) questions with three-answer choice.

\begin{tabular}{cll}
\hline Number & \multicolumn{1}{c}{ Questions } & \multicolumn{1}{c}{ Possible Answer Choices } \\
\hline 1 & Do you like to live in Flats? & 1. Yes (Agree) \\
\multirow{2}{*}{2} & Do you like to live in & 2. No (Disagree) \\
& Mid-Terraced Houses? & 3. Not Known \\
\hline
\end{tabular}

\section{Path Two (P2)}

Establishment of 5D BIM as well as an estimation of construction costs (Quantitative)

This study suggests a new design to analyze precisely the project costs of KSA construction projects and to support fiscal decision making for contractors based on 5D BIM. The structure considers quantities of tools, quantities of the workforce, and quantities of resources, the schedule of project, payment period, and the lead-time of material orders in order to estimate the definite project elements. Moreover, decision makers and contractors can compare several substitutes over considering the diverse strategies for the smooth running of the project.

In order to formulate a 5D BIM, four key phases are required. They are

i. $\quad$ Generation of 3D BIM

ii. Bill of Quantities (BOQ)

a. Quantity Take-Off (QTO) extraction

b. Bill preparation 
- Estimate of volumes, areas, etc.

- Entering the portrayals and squared dimensions

- Accumulating objects together and offering in a recognized bill order

iii. Schedule data and Quantity take-off integration

iv. Data of costs and agenda laden QTO list amalgamation and synchronization

However, a BIM comprises complete semantic and geometric material and can be transferred to a $5 \mathrm{D}$ software platform to produce a BOQ. By connecting the Quantity take-off tilt with the outward timetable catalogue, the schedule-loaded Quantity take-off tilt is created. By assimilating the schedule-loaded Quantity take-off tilt with the outward cost catalogue, the cost-loaded project can be assessed. The cost-loaded timeline folder can then be introduced to the $5 \mathrm{D}$ platform to generate a 5D BIM and comportment 5D simulation. In this process, time management and clash detections are very vital.

\section{Results and Discussion}

\subsection{Path One (P1)}

\section{Surveying}

Survey results reflected the views of 365 responses of selected communities, participants were mainly from:

- $\quad$ Riyadh-75

- Jeddah-78

- Makkah-65

- Eastern Region-53

- $\quad$ Other places-94

These results were analyzed and used as supporting data to evaluate the housing style choices as a part of this study. Of the 365 respondents, the majority of the respondents did not like the flats but expressed an interest in terraced houses/individual houses. Moreover, an insignificant number of respondents were fairly neutral (Figures 4 and 5).

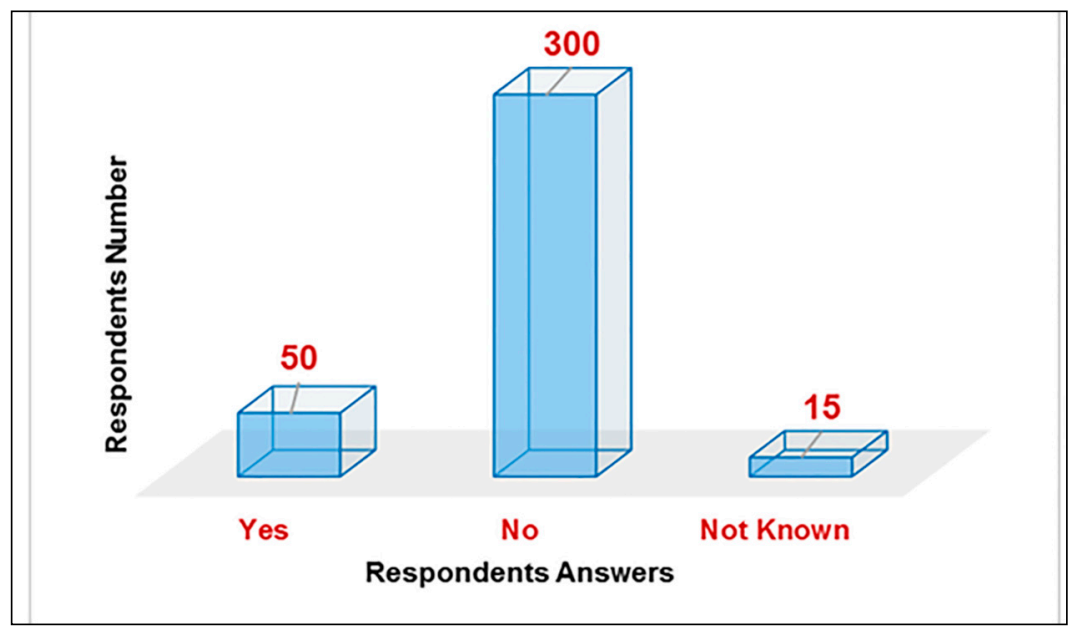

Figure 4. Quantitative survey (5 pilot studies—question -1), respondent answer patterns. 


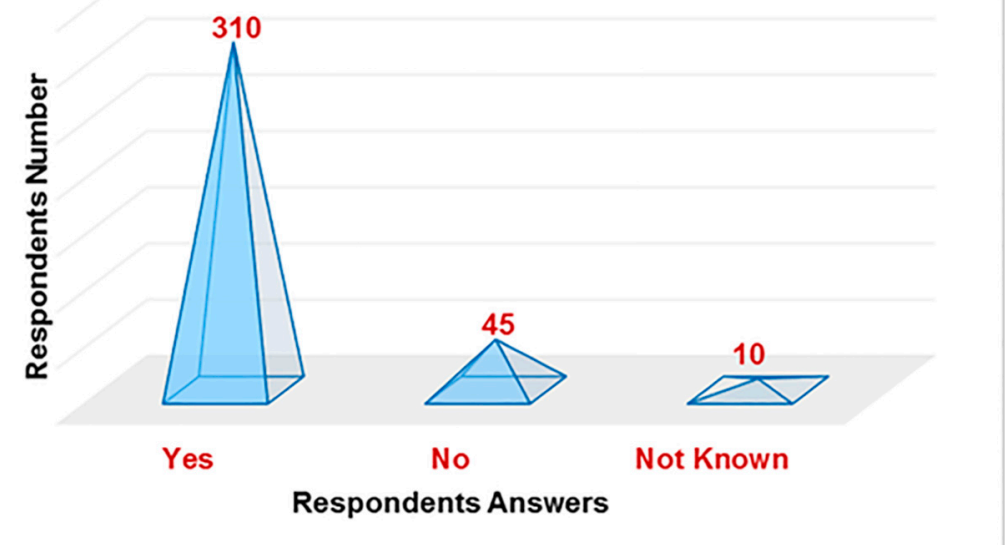

Figure 5. Quantitative survey (5 pilot studies—question -2), respondent answer patterns.

\subsection{Path Two (P2)}

\subsubsection{Establishment of 5D BIM}

With a comprehensive design, the goal of this 5D BIM is to offer a graphic design appraisal with dynamic links to the model material that will offer a base living cost plan that can be used for developing design and bidding activities. As mentioned in early paragraphs, 3D CAD models are very popular in the BIM. However, $4 \mathrm{D}$ and 5D models are gaining popularity rapidly due to their unique futures (Table 2). This study examined the designs of Mid-Terrace houses (designed with Vico and ArchiCAD software). Initially 3D CAD models were created (Figures 6a-d and 7) using ArchiCAD software for the proposed houses and were then published and exported to Vico software.

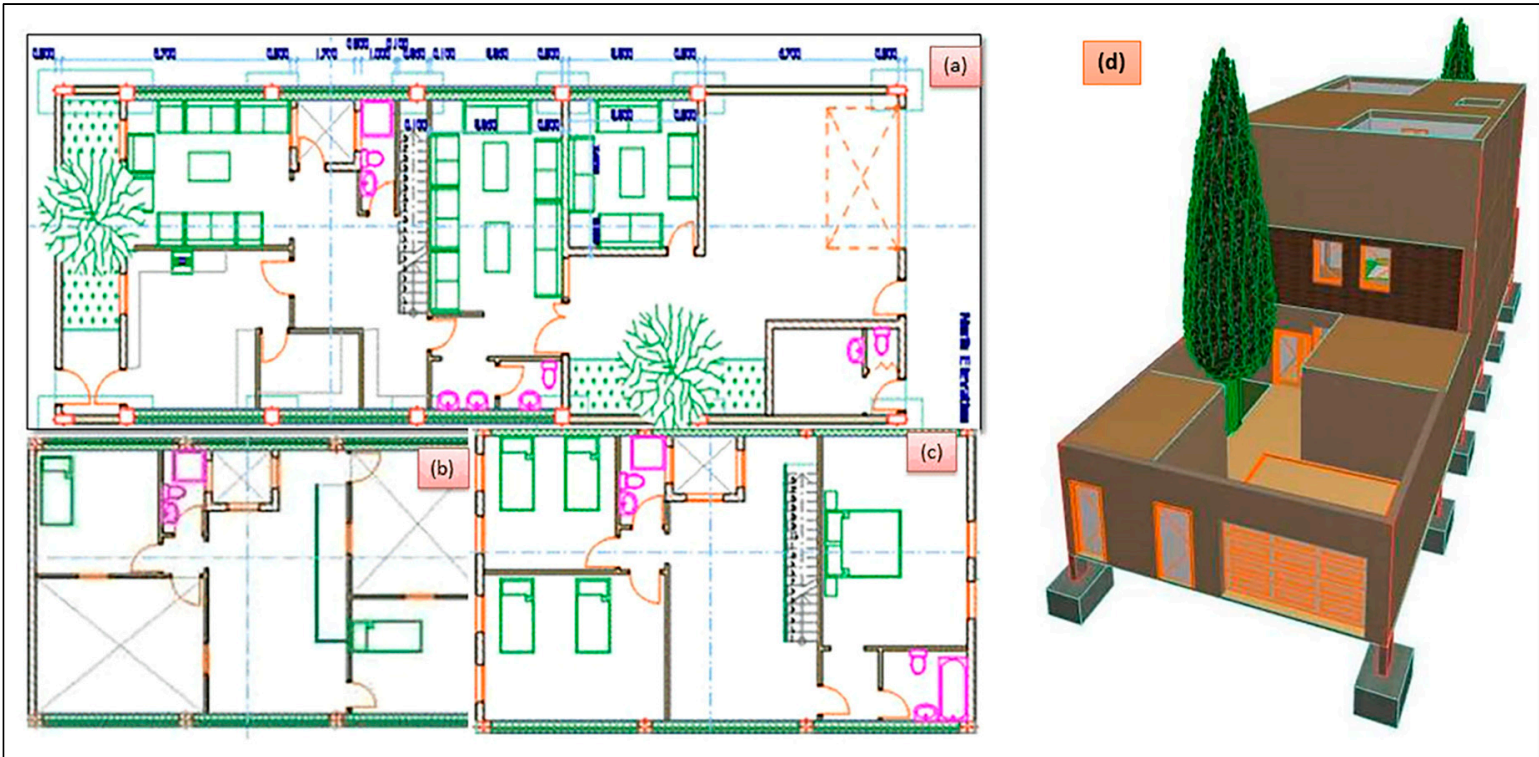

Figure 6. (a) Ground floor plan of the proposed design; (b) Second floor plan of the proposed design and; (c) Frist floor plan of the proposed design (d) 3D perspective of proposed house. 


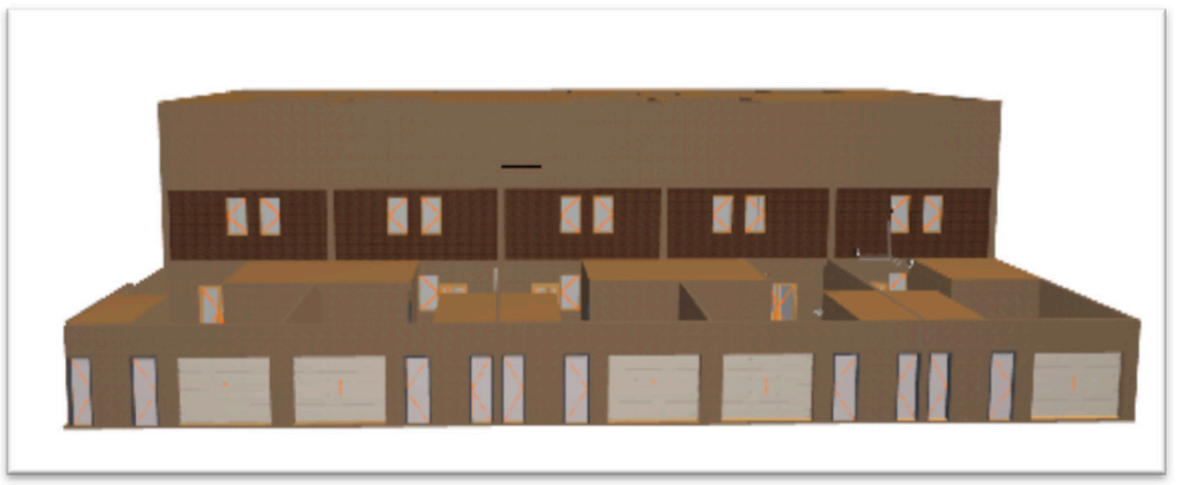

Figure 7. Perspective for block of mid-terrace houses.

After exporting designs to Vico, we then activated the 3D models and created a library of Materials codes (LMC), including a unit price for each item (or building material) that helps users for Saudi construction projects. From there, they were imported into Excel software to automatically validate and calculate the accurate quantities from the model, including recalculating many versions of the same project in case of a change, or a design alteration, to obtain the final BOQ for the proposed mid-terraced houses. (Figures 8 and 9).

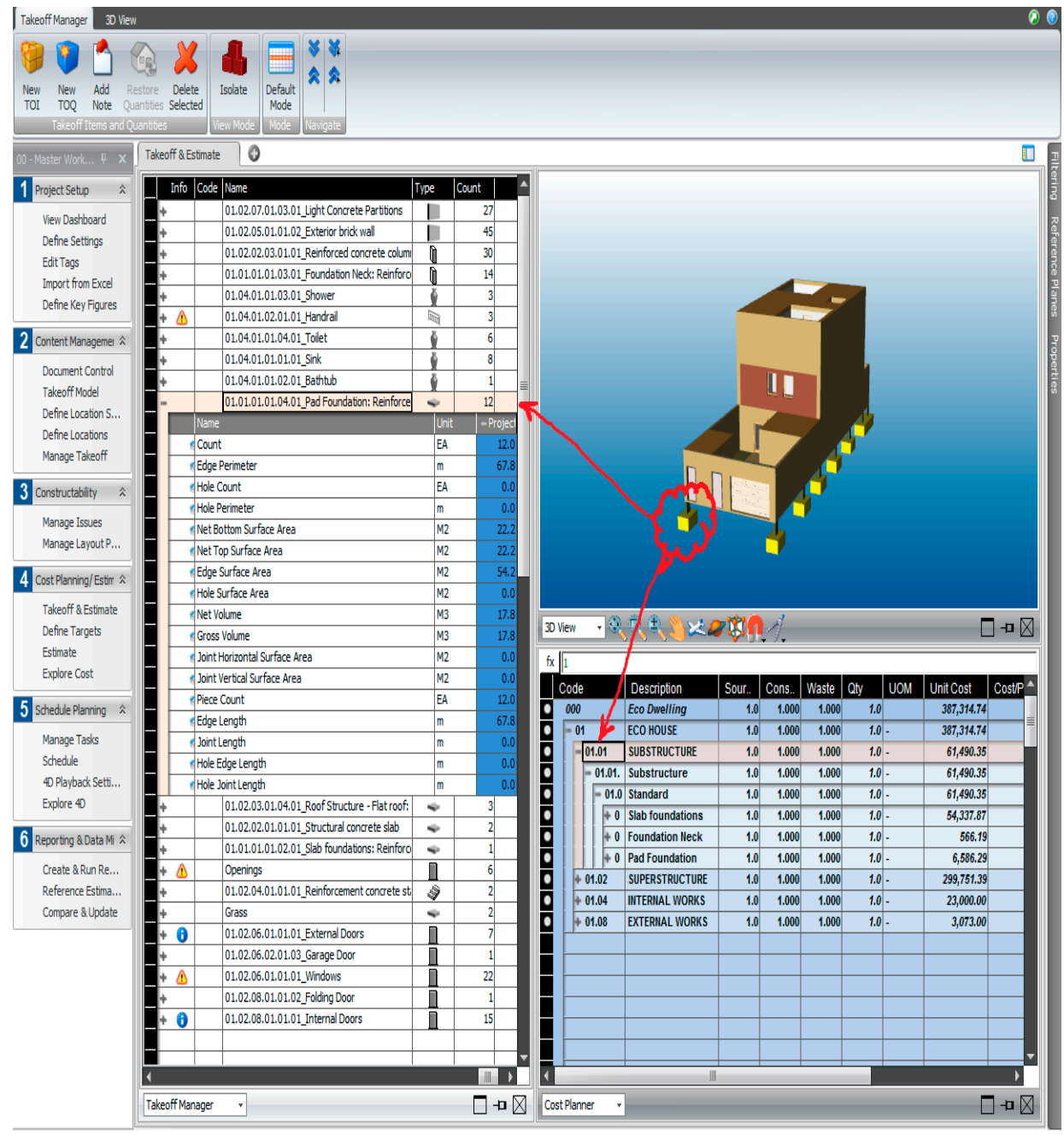

Figure 8. Take-off and cost estimation integrated with the 3D Model. 


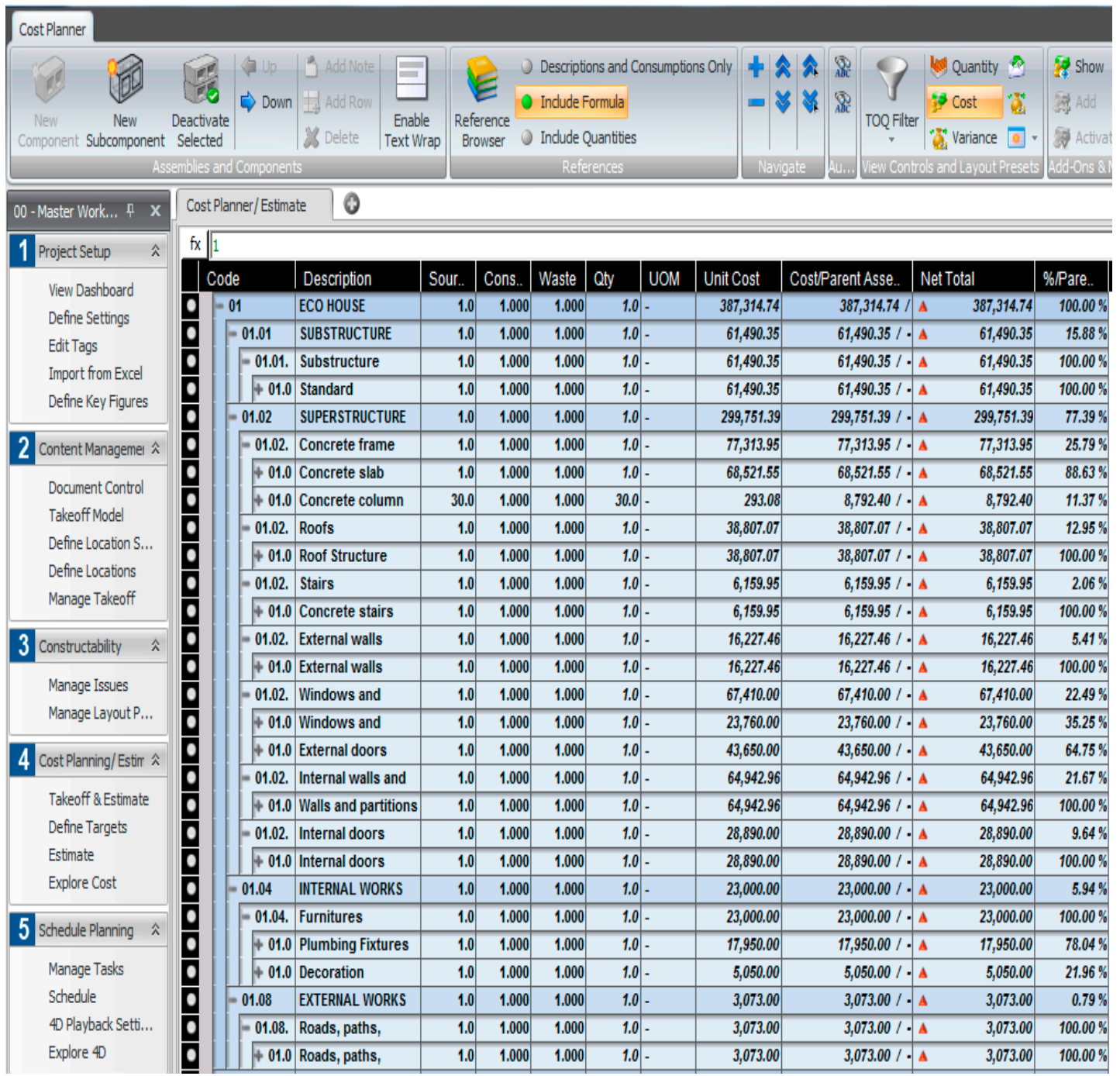

Figure 9. Summary of the Bill of quantities (BOQ) as it appears on the Vico software.

For instance, identifying and coding any item, such as a slab foundation, needs to have the following description: 1.01.01.01.02.01_Slab foundations: Reinforced concrete, $200 \mathrm{~mm}$ depth, C30, $350 \mathrm{~kg} / \mathrm{m}^{3}$, power floated finish, Net Volume, and unit cost, e.g., SAR1000 (£200). Consequently, it needs to be linked and integrated into the same item/material in the 3D ArchiCAD model along with the schedule and cost data. Creating a library of codes (LOC) for Saudi construction projects, (Figure 10) including a unit price for each item (or building material) helps users. Figure 10 shows extracts from the library of codes required for the production of a bill of quantities with unit prices. Consequently, it needs to be linked and integrated into the same item/material in the 3D ArchiCAD model along with the schedule (Gantt Chart-Figure 8) and cost data. While, the Gantt chart of the project schedule illustrates the time and dependency for each activity, the Critical Path Method (CPM) for the project, and the completion date. 


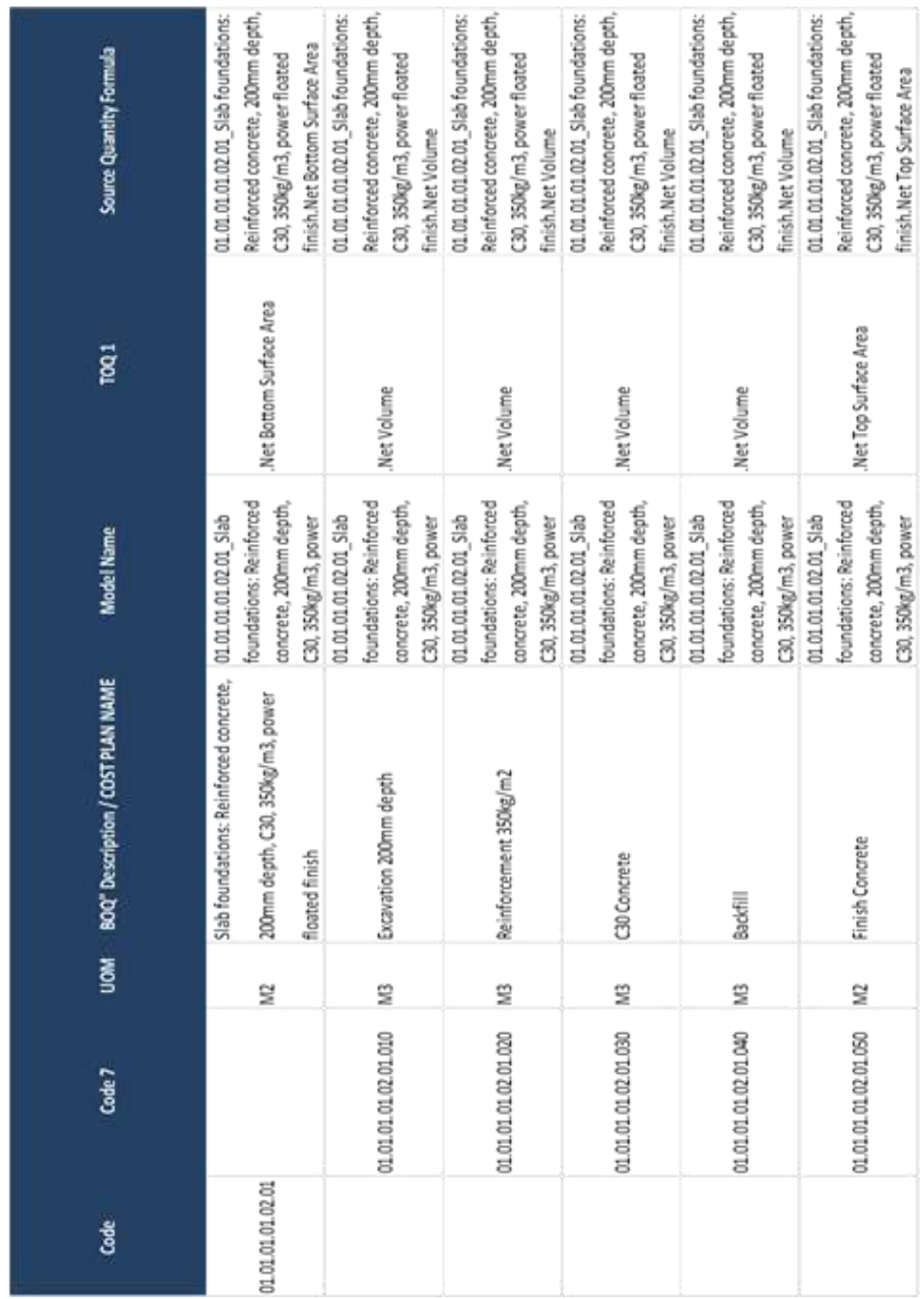

Figure 10. Extract from the library of codes (LOC) required for the production of a bill of quantities with unit prices.

By creating a LOC for Saudi construction projects, complete with the unit prices for each item (i.e., labor, plant and materials), users can link and integrate the 3D model created and exported by ArchiCAD to Vico Office software. This can be automatically validated and calculated for accurate quantities from the model, including recalculating many of the versions of the same project in case of 
changing an order or with design alterations to get the final BOQ. For instance, to identify and code any item, such as slab foundations, it needs to be described as the following:

Code 01.01.01.01.02.01_Slab foundations: Reinforced concrete, $200 \mathrm{~mm}$ depth, C30, $350 \mathrm{~kg} / \mathrm{m}^{3}$, power floated finish. Consequently, this needs to be linked and integrated to the same item $/ \mathrm{materials}$ in the 3D ArchiCAD model with the schedule and cost data (Figure 11).

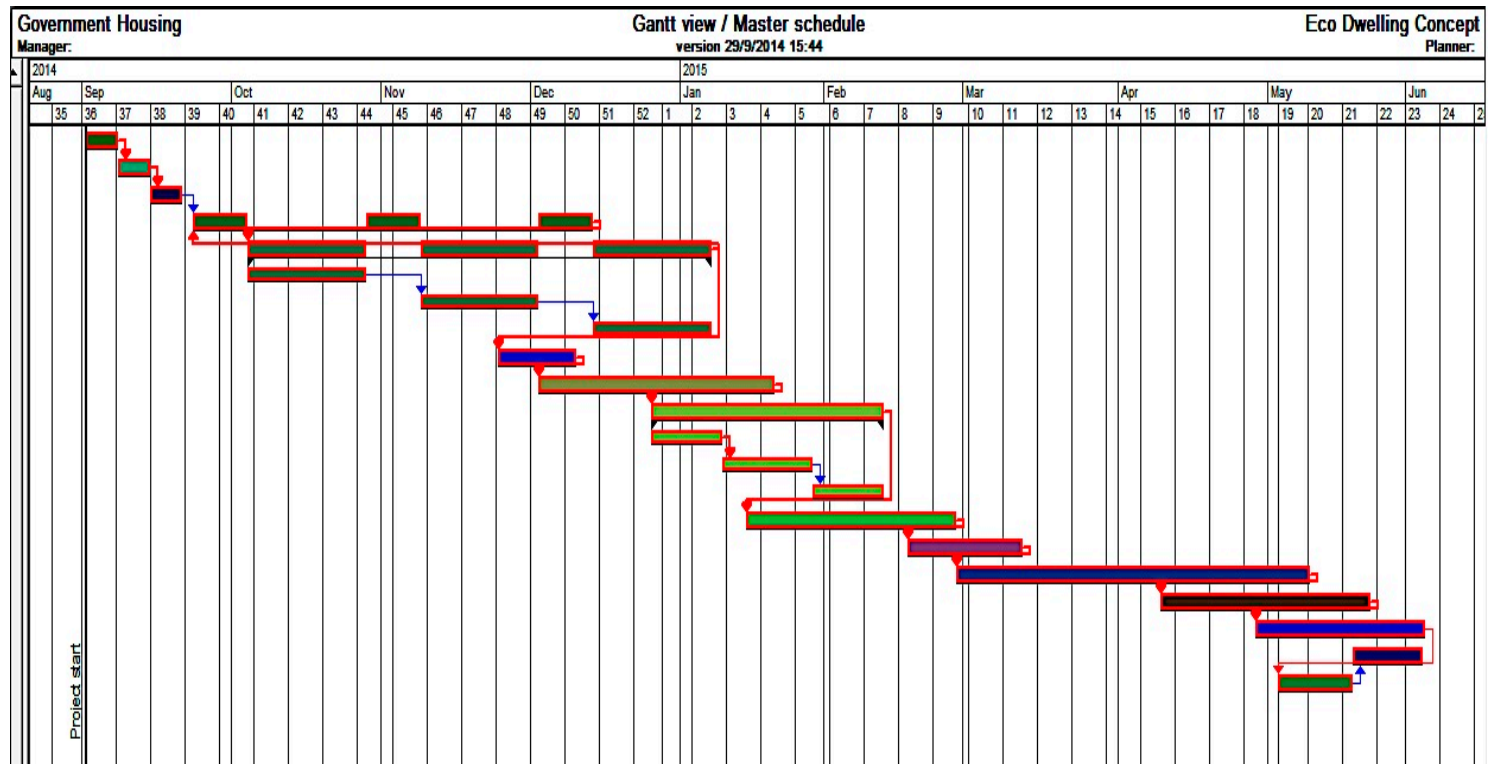

Figure 11. Gantt chart of the project schedule.

\subsubsection{Time Management/Schedule}

The flow-line schedule (Figure 12) helps to illustrate the group activity on the worksite. The $X$-axis represents the schedule, while the $Y$-axis represents the location of activities on the worksite. The colored lines represent each activity group, and the slope of the lines indicates their productivity rate.

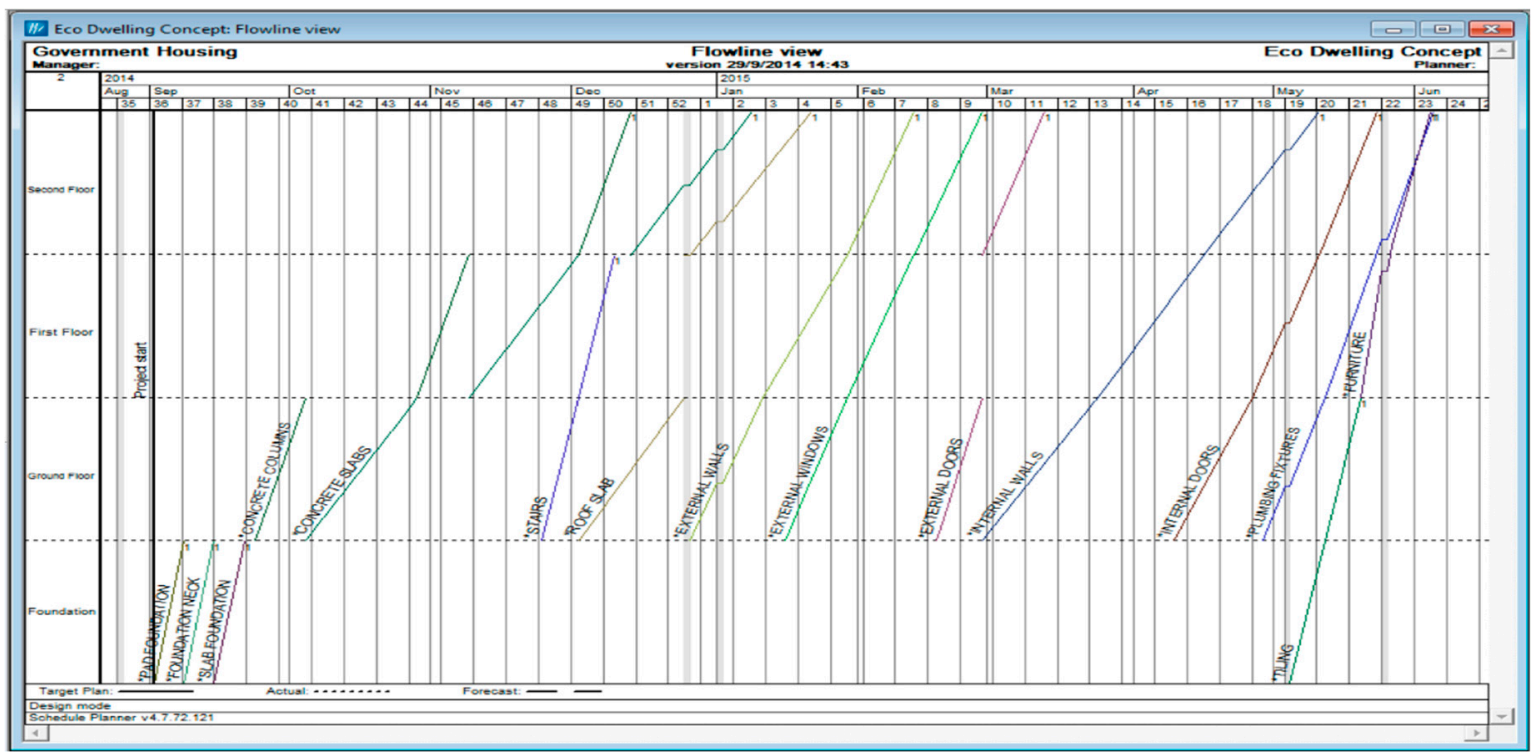

Figure 12. Schedule Planner-Flow line. 


\subsubsection{Clash Detection}

Clash detection and data integrity are very important features for project quality and quantity (Figure 13). Instant identification and resolution of any discrepancy can be achieved with automated clash analysis technology with 3D BIM Models. The use of these technologies makes it possible to speed up on-site work, improve building quality and track the accuracy of the bill of quantities. The use of automated clash analysis technology, as well as 3D Modelling, minimizes the waste of materials and reduces the number of time delays and changes that can be encountered before, and during, the construction stages.

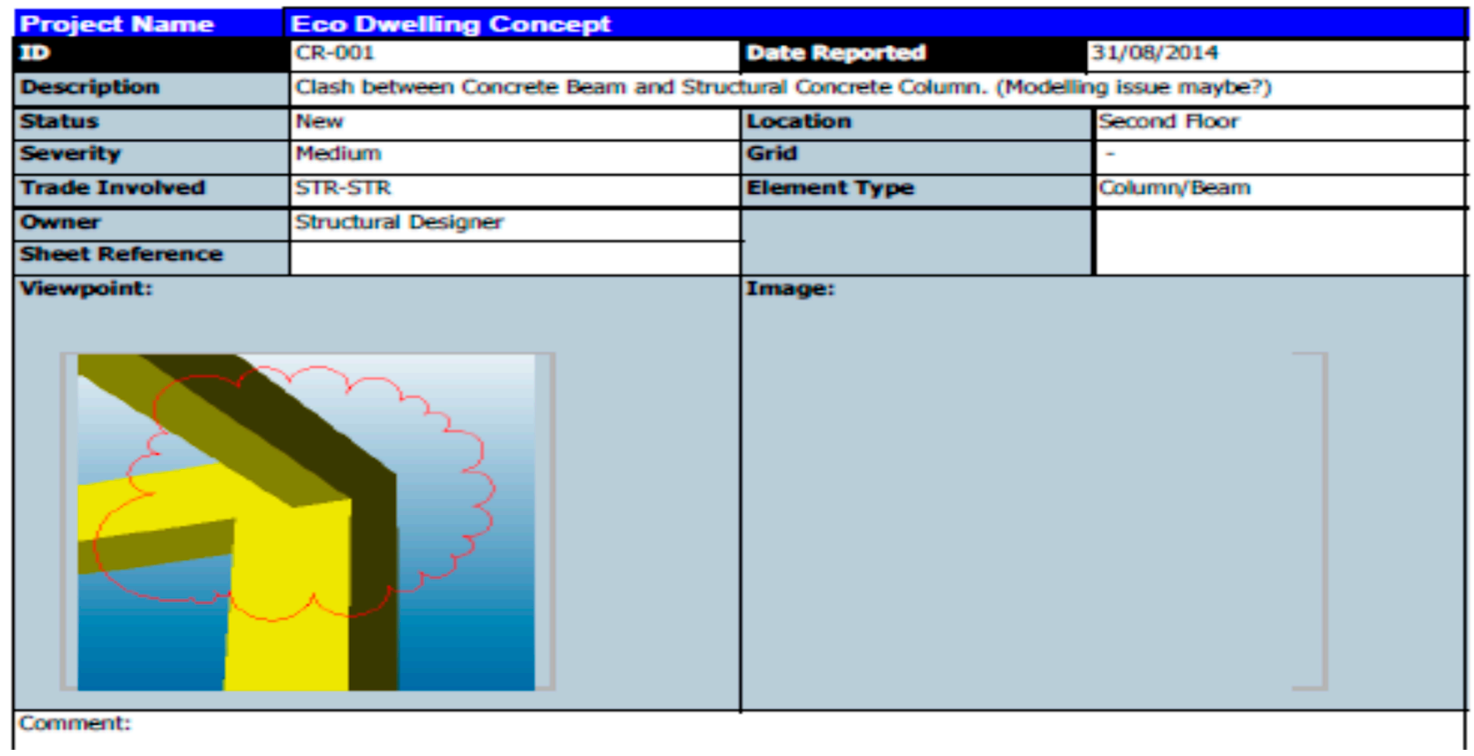

Figure 13. Illustration of the clash between column and beam.

The current 3D BIM is based on traditional geometry-based 3D CAD, object-oriented CAD, and parametric building modeling technologies. It provides intelligent project information (incorporating non-graphic information such as material descriptions and specifications, cost and schedule information, and construction methods) about building components; it is also capable of coordinating related elements when a variable (drawing parameter or building design information parameter including the structural load, component attribute, thermal property, weight, etc.) is changed.

\subsubsection{Estimating the Cost of the Proposed Mid-Terrace House in Comparison with a Flat House}

Table 3 illustrates that a mid-terraced house cost is fairly higher than a flat but the land area is lesser than a flat. However, total built area is greater. Both communities and government are interested in these types of houses.

Table 3. Comparison of Mid-Terrace and Flat houses in Fiscal Perspectives.

\begin{tabular}{ccccc}
\hline Type of Housing & $\begin{array}{c}\text { Cost in Thousands } \\
\text { Including Cost of Land } £^{*}\end{array}$ & Area of Land & $\begin{array}{c}\text { Main Utilities } \\
\text { Water Tank, Sewage }\end{array}$ & $\begin{array}{c}\text { Parking \& } \\
\text { External Entrance }\end{array}$ \\
\hline Flat & 130,000 & Shared $243 \mathrm{M}^{2}$ & Shared & Shared \\
\hline \multirow{2}{*}{ Mid-Terrace } & 137,400 & $\begin{array}{c}\text { Independent land } \\
200 \mathrm{M}^{2}-\text { Total built } \\
\text { areas } 312 \mathrm{M}^{2}\end{array}$ & Independent & Independent \\
\hline & ${ }^{*} £ 1=$ SAR 5.
\end{tabular}




\section{Comparison between the Traditional and 5D BIM Methods Results}

To compare between traditional and modern methods, the traditional methods use simple tools and software, such as Excel, to calculate unit prices and historical data for projects. Cutting-edge software methods consist of different techniques that are implemented in this study. The initial cost-estimation for construction was estimated by the Ministry of Housing as being in the range of SAR 440,000 (£88,000), plus the cost of land for a detached house and SAR was $650,000(£ 130,000)$ for a flat house with a total area of 243 square meters $\left(\mathrm{M}^{2}\right)$. This was compared with the proposed design of a Mid-Terrace house in this paper. The lowest value was SAR 440,000 (£88,000) for a detached house and SAR 400,000 (£80,000) for a flat house. However, the cost estimation of this construction project with a total area of $312 \mathrm{M}^{2}$, using 5D BIM, was SAR 387,314 (£77,463) plus SAR 299,685 $(£ 59,937)$ as a cost of land to be a total of SAR $685,000(£ 137,400)$. The 5D BIM estimate represents $88 \%$ of the lowest cost of a detached house. Even so, it represents $114 \%$ of the lowest cost and $102 \%$ of the initial cost estimation of the flat cost with less area. As a result, the 5D BIM estimation provides a more accurate bill of quantities than the traditional method, thus leading to more precise cost estimates

\section{Conclusions}

Saudi Arabia's lodging target is under a great risk. As per the accordance by the kingdom to import adequate building materials, there is as of now an ascent in the business wages. The kingdom needs to develop 500,000 properties for low-pay occupants to help encourage housing security and meet the typical population increase. Hence, 5 pilot surveys were conducted to know the public's opinion on the housing styles across the KSA, in particular in major cities. The analysis revealed that; most of the people like to live in independent houses or mid-terraced houses rather than flats. This survey supported this study to further the consideration of 5D BIM. However, an onslaught demand for building materials had increased expenses by $20 \%$. To reduce the costs, land area and time, a 5D BIM with LMC was created and developed for flat vs. mid-terraced houses in KSA, which fulfilled the needs of average families. This 5D BIM significantly reduces the construction costs by saving material waste and construction project time by clash detection, gaining accurate planning and scheduling. Unquestionably, this model will be useful to the contractors, BIM managers, architects and government.

Author Contributions: K.K. and I.A. designed the study, and Komali Kantamaneni designed methodology. I.A. preformed the analysis by using various software.

Funding: This project was funded by Ministry of Municipal and Rural Affairs, KSA via PhD scholarship No. MUA012.

Acknowledgments: We would like to give special thanks for the comments of three anonymous reviewers on an earlier version, which contributed significantly to the improvement of the manuscript.

Conflicts of Interest: The authors declare no conflict of interest.

\section{References}

1. Jrade, A.; Alkass, S. Computer-integrated system for estimating the costs of building projects. J. Arch. Eng. 2007, 13, 205-223. [CrossRef]

2. Sidawi, B. Incorporating lifestyle in the design of affordable housing in Saudi Arabia Kingdom. Emir. J. Eng. Res. 2008, 2, 67-72.

3. Affordable House Company (AHC). Profile. 2012. Available online: http://www.zawya.com/middle-east/ company/profile/11010649/Affordable_House_Company/ (accessed on 12 October 2012).

4. Bateman, R.; Majdalawieh, M. Megaprojects and risk management: Emaar Properties. Int. J. Teach. Case Stud. 2009, 2, 56-75. [CrossRef]

5. Fadaak, T.A. Urban Housing Policy Evaluation in the Kingdom of Saudi Arabia. Ph.D. Thesis, Portland State University, Portland, OR, USA, 1984. 
6. Rahimian, F.P.; Ibrahim, R.; Goulding, J.; Ali, A.A.A. Proceedings of 1st International Conference on Revisiting the Socio-Political and Technological Dimensions of Climate Change; University of Central Lancashire (UCLan): Preston, UK, 2012.

7. Opoku, R.A.; Abdul-Muhmin, A.G. Housing preferences and attribute importance among low-income consumers in Saudi Arabia. Habitat Int. 2010, 34, 219-227. [CrossRef]

8. Al Surf, M.S.; Susilawati, C.; Trigunarsyah, B. The role of the Saudi government and the Saudi building code in implementing sustainable housing construction in Saudi Arabia. In Proceedings of the 20th Annual Pacific-RIM Real Estate Society Conference, Christchurch, New Zealand, 19-22 January 2014.

9. Azhar, S.; Nadeem, A.; Mok, J.Y.; Leung, B.H. Building Information Modeling (BIM): A new paradigm for visual interactive modeling and simulation for construction projects. In Proceedings of the First International Conference on Construction in Developing Countries, Karachi, Pakistan, 4-5 August 2008; pp. 435-446.

10. Zhang, J.; Hu, Z. BIM-and 4D-based integrated solution of analysis and management for conflicts and structural safety problems during construction: 1. Principles and methodologies. Autom. Constr. 2011, 20, 155-166. [CrossRef]

11. Jackson, B.J. Construction Management JumpStart: The Best First Step Toward a Career in Construction Management; John Wiley and Sons: Hoboken, NJ, USA, 2010.

12. Curry, E.; O’Donnell, J.; Corry, E.; Hasan, S.; Keane, M.; O'Riain, S. Linking building data in the cloud: Integrating cross-domain building data using linked data. Adv. Eng. Inform. 2013, 27, 206-219. [CrossRef]

13. Watson, A. Digital buildings-Challenges and opportunities. Adv. Eng. Inform. 2011, 25, 573-581. [CrossRef]

14. Epstein, E. Implementing Successful Building Information Modeling; Artech House: Norwood, MA, USA, 2012.

15. Mitchell, D. 5D BIM: Creating cost certainty and better buildings. In Proceedings of the RICS COBRA 2012-The Annual RICS International Research Conference, Las Vegas, NV, USA, 11-13 September 2012; pp. 1-9.

16. Eastman, C.; Eastman, C.M.; Teicholz, P.; Sacks, R. BIM Handbook: A Guide to Building Information Modeling for Owners, Managers, Designers, Engineers and Contractors; John Wiley \& Sons: Hoboken, NJ, USA, 2011.

17. Thomsen, C.; Faia, F. Integrated Project Delivery: An Overview; CMAA: Alexandria, VA, USA, 2009.

18. Lee, C.S. Implementation of Integrated Project Delivery on Department of Navy Military Construction Projects. Master's Thesis, University of Nevada, Las Vegas, NV, USA, 2013.

19. Bryde, D.; Broquetas, M.; Volm, J.M. The project benefits of building information modelling (BIM). Int. J. Proj. Manag. 2013, 31, 971-980. [CrossRef]

20. Popov, V.; Juocevicius, V.; Migilinskas, D.; Ustinovichius, L.; Mikalauskas, S. The use of a virtual building design and construction model for developing an effective project concept in 5D environment. Autom. Constr. 2010, 19, 357-367. [CrossRef]

21. Gao, J.; Fischer, M. Framework and Case Studies Comparing Implementations and Impacts of 3D/4D Modeling across Projects; Stanford University: Stanford, CA, USA, 2008.

22. Forgues, D.; Iordanova, I.; Valdivesio, F.; Staub-French, S. Rethinking the cost estimating process through 5D BIM: A case study. In Proceedings of the Construction Research Congress 2012: Construction Challenges in a Flat World, West Lafayette, IN, USA, 21-23 May 2012; pp. 778-786.

23. Marzouk, M.; Metawie, M.; Hisham, M.; Al-Sulahi, I.; Kamal, M.; Al-Gahtani, K. Modeling Sustainable Building Materials in Saudi Arabia. In Computing in Civil and Building Engineering; ASCE: Reston, VA, USA, 2014; pp. 1546-1553.

24. Jung, Y.; Joo, M. Building information modelling (BIM) framework for practical implementation. Autom. Constr. 2011, 20, 126-133. [CrossRef]

25. Popov, V.; Migilinskas, D.; Juocevicius, V.; Mikalauskas, S. Application of Building Information Modeling and Construction Process Simulation Ensuring Virtual Project Development Concept in 5D Environment. In Proceedings of the 25th International Symposium on Automation and Robotics in Construction, Vilnius, Lithuania, 26-29 June 2008.

26. Mills, A.; Love, P.E.; Williams, P. Defect costs in residential construction. J. Constr. Eng. Manag. 2009, 135, 12-16. [CrossRef]

27. Broekmaat, M. The 5D BIM Connection to Estimating. 2008. Retrieved August 6, 2014. Available online: http:/ / www.vicosoftware.com/blogs/vicos_flying_dutchman/tabid/47083/bid/4451/ The-5D-BIM-Connection-to-Estimating.aspx (accessed on 12 October 2018). 
28. Wang, H.; Zhang, J.; Chau, K.; Anson, M. 4D dynamic management for construction planning and resource utilization. Autom. Constr. 2004, 13, 575-589. [CrossRef]

29. Russell, A.; Staub-French, S.; Tran, N.; Wong, W. Visualizing high-rise building construction strategies using linear scheduling and 4D CAD. Autom. Constr. 2009, 18, 219-236. [CrossRef]

30. Zhang, S.; Teizer, J.; Lee, J.-K.; Eastman, C.M.; Venugopal, M. Building information modeling (BIM) and safety: Automatic safety checking of construction models and schedules. Autom. Constr. 2013, 29, 183-195. [CrossRef]

31. McCuen, T.L. Scheduling, estimating, and BIM: A profitable combination. In Proceedings of the AACE International Transactions, BIM11, Toronto, ON, Canada, 29 June-2 July 2008.

32. Winkler, H.; Fecher, R.S.; Tyani, L.; Matibe, K. Cost Benefit Analysis of Energy Efficiency in Low-Cost Housing; University of Cape Town: Cape Town, South Africa, 2016.

33. Pishdad-Bozorgi, P.; Moghaddam, E.H.; Karasulu, Y. Advancing target Price and target value design process in IPD using BIM and Risk-Sharing Approaches. In Proceedings of the 49th ASC Annual International Conference Proceedings, San Luis Obispo, CA, USA, 9-13 April 2013.

34. Mouflard, C. Bringing 5D to the Jobsite with Production Control; Trimble Navigation, Ltd.: Sunnyvale, CA, USA, 2013.

35. Philipp, N.H. Building information modeling (BIM) and the consultant: Managing roles and risk in an evolving design and construction process. Proc. Meet. Acoust. 2013, 19, 015095.

36. Yung, P.; Wang, X. A 6D CAD model for the automatic assessment of building sustainability. Int. J. Adv. Robot. Syst. 2014, 11, 131. [CrossRef]

37. Zhou, Y.; Ding, L.Y.; Luo, H.B.; Chen, L.J. Research and application on 6D integrated system in metro construction based on BIM. In Applied Mechanics and Materials; Trans Tech Publications: Zürich, Switzerland, 2010; pp. 241-245.

38. SPRINGFIELD. Mid-Terrace Housing. 2014. Available online: http://www.springfield.co.uk/ (accessed on 6 June 2018).

39. CPI Media Group. BIG PROJECTT_KSA to Build 200,000 Affordable Housing Units; Housing Project: Abu Dhabi, UAE, 2014.

40. Gill, A.; Biger, N.; Mathur, N. The effect of capital structure on profitability: Evidence from the United States. Int. J. Manag. 2011, 28, 3.

41. The Sun. Who you gonna call? Real-life ghostbusters called to London apartment block to banish 'ghoul that's been terrorising residents. Available online: https:/ /www.thesun.co.uk/archives/news/258915/whoyou-gonna-call-real-life-ghostbusters-called-to-london-apartment-block-to-banish-ghoul-thats-beenterrorising-residents/ (accessed on 6 June 2018).

42. CBSE (Centre for the study of Built Environment). Riyadh Architecture in One Hundred Years. Available online: http:/ / new.csbe.org/publications-and-resources/articles-and-lectures-on-architecturalissues / riyadh-architecture-in-one-hundred-years / (accessed on 6 June 2018).

43. Kantamaneni, K.; Alrashed, I.; Phillips, M. Cost vs. Safety: A novel design for tornado proof homes. HBRC J. 2017, 13, 223-232.

(C) 2018 by the authors. Licensee MDPI, Basel, Switzerland. This article is an open access article distributed under the terms and conditions of the Creative Commons Attribution (CC BY) license (http://creativecommons.org/licenses/by/4.0/). 